\title{
|فْتاحية المعد
}

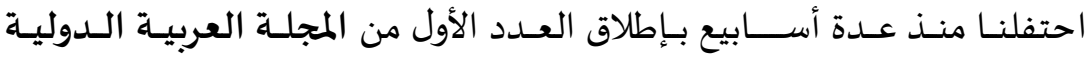

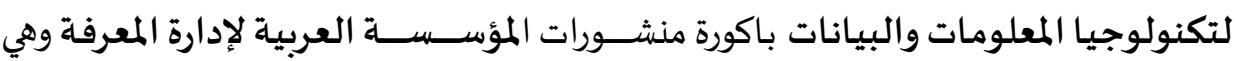

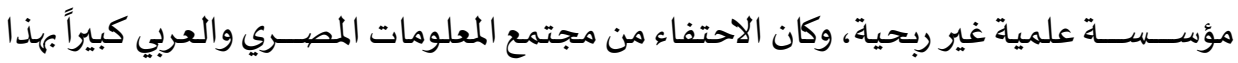

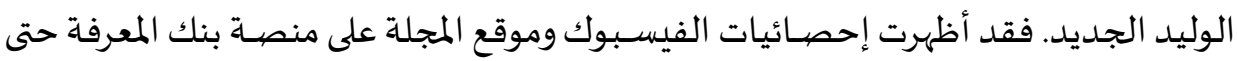
كتابة هذه السطور إقبالاً كبيراً على المجلة تمثل فيما يلي: 1- عدد مرات الإعجاب التي حظيت بها صــفحة المجلة أكثر من 1100 إعجاب، ولا زال

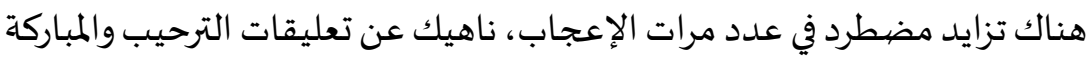
والإشـادة.

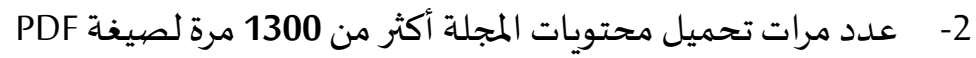

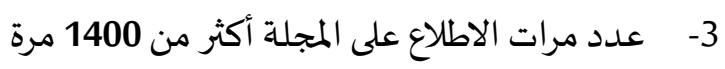

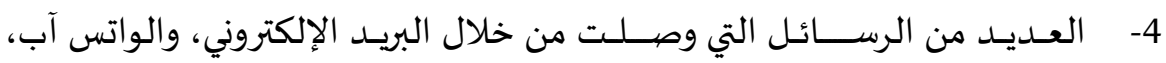
والماسنجر تسفسر عن كيفية الإسهام في المجلة.

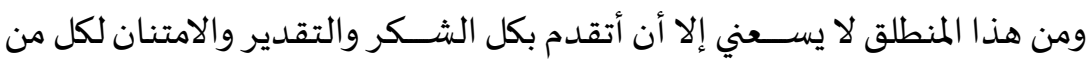

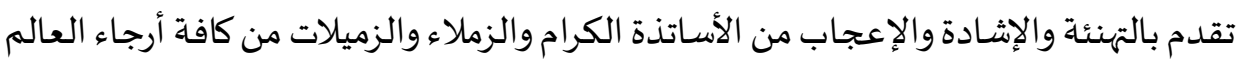
العربي، فقد كان مرورهم هذا بمثابة باقـة حب طوقت أعناقنا في هيئة تحرير المجلة الهنة وأعطتنا

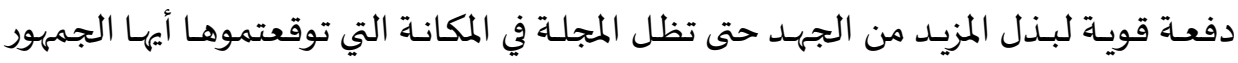

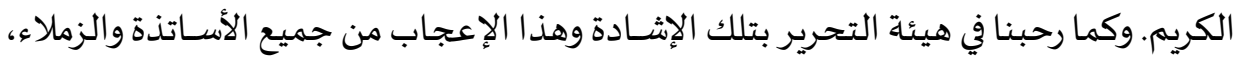

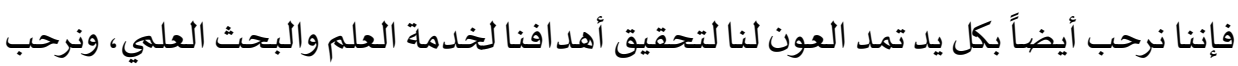

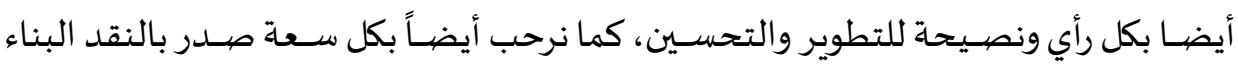

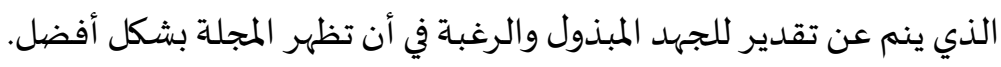
وترحب المجلة بكل شــدة بتلك الإسـهامات المتميزة التي تتوافق مع سـياســة تحرير المجلة من كل أنحاء العالم. 


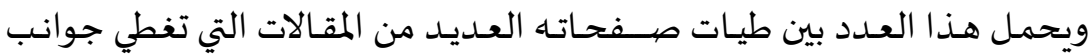

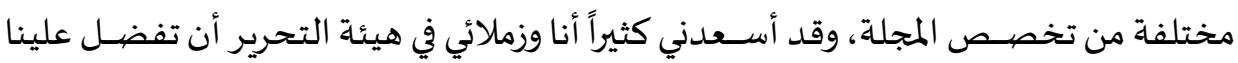

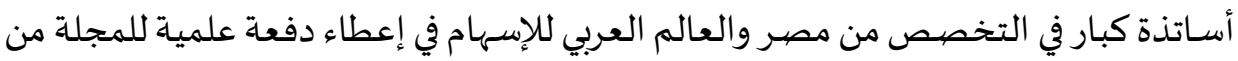

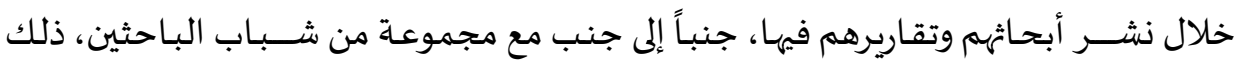

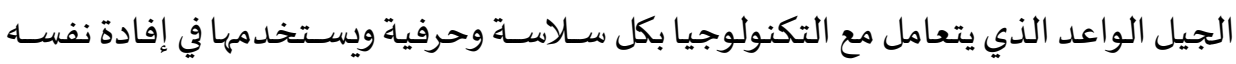
وغيره من المتعاملين مع مؤسسات المعلومات المختلفة.

أقدر وبكل شـــدة مجهود زملائي الأفاضــل في هيئة التحرير على الجهد المبذول لكي

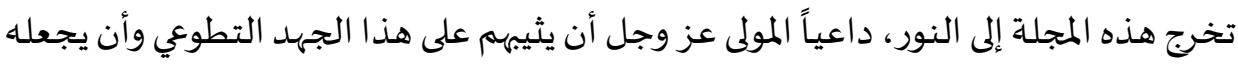
في ميزان حسناتهم. كما أتقدم بكل الشكر والتقدير للأسـاتذة الكرام الذين تطوعوا لتحكيم المقالات في هذا العدد عن حب وود، إنطلاقاً من صلة الرحم بين أهل العلم. وفي الههاية أرحب بالمجلتين الجديدتين اللتان صــدرتا في مســهل عام 2022 وهما

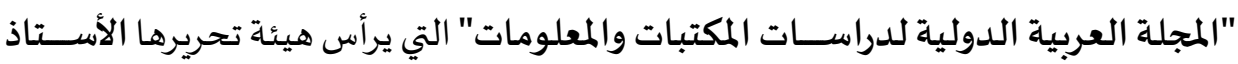

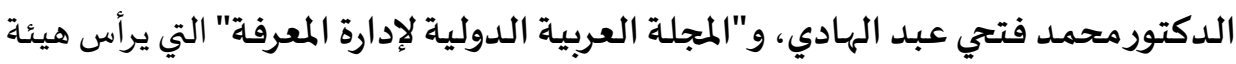

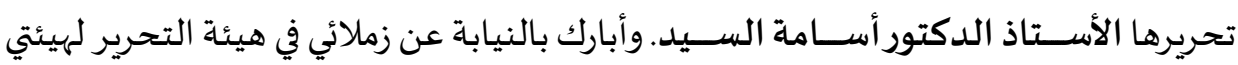

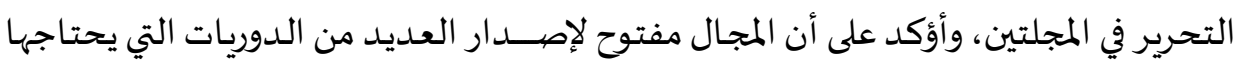
مجالنا المعلوماتي، ففي أرض العلم متسع للجميع. وآخردعو انا أن الحمد لله رب العالمين

أ.د. خالد الحلبي

رئيس التحرير 